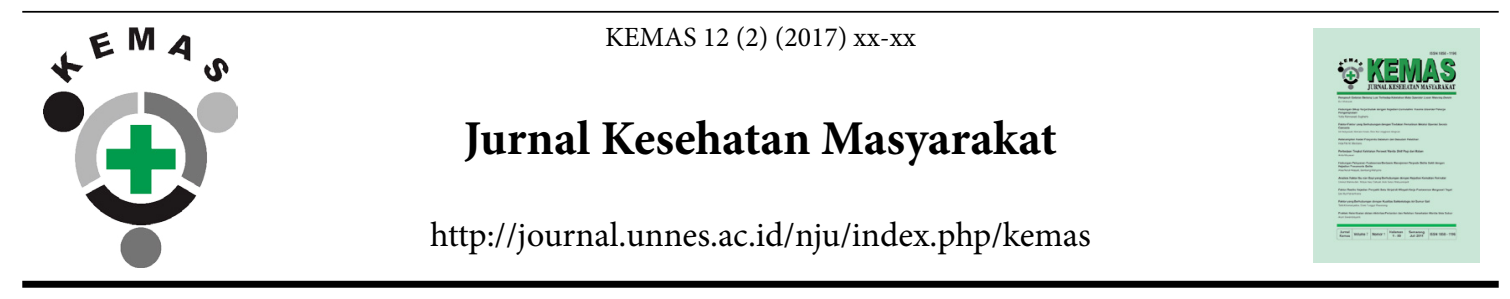

\title{
HEALTH SERVICES, MATERNAL INTRINSIC AND SOCIO-CULTURAL FACTORS AND PERINATAL MORTALITY
}

\author{
A. A. Diaz Viera ${ }^{\bowtie}$, M. R. Pellokila, Rafael Paun \\ Public Health Department, Post Graduated Programe, Universitas Nusa Cendana Kupang, Indonesia
}

\section{Article Info}

Article History:

Submitted 20 April 2016

Accepted 12 October 2016

Published January 2017

Keywords:

Perinatal; Mortality; Financing; Disease; Perinatal

DOI

http://dx.doi.org/10.15294/

kemas.v11i1.3521

\begin{abstract}
This study question was how significant the determination of health services, maternal intrinsic risk factors and socio-cultural factors on perinatal mortality. Its objective was to construct a model of perinatal mortality pattern by case-control design. The case population was all mothers with perinatal mortality. The sample-size was 35 by simple random sampling with case-control ratio of 1:1 (35:35). The data analysis applied Bivariate using Chi Square Test and Multivariate using Logistic Regression Test. The Bivariate Analysis Results found the risk-variables on Perinatal Mortality were Birth Attendant $(\mathrm{OR}=2.1 ; 1.63-2.7 ; 95 \% \mathrm{CI})$, Health Financing $(\mathrm{OR}=7.1 ; 1.82-27.8 ; 95 \% \mathrm{CI})$, Maternal Disease History $(\mathrm{OR}=8 ; 2.05-31.16$; 95\%CI), Perinatal History $(\mathrm{OR}=6.47 ; 2.26-18.55$; 95\%CI) and Custom $(\mathrm{OR}=2.17 ; 1.67-2.82 ; 95 \% \mathrm{CI})$. Multivariat Analysis found three consistent risk variables on Perinatal Mortality i.e.: Health Financing $(\mathrm{p}=0.016 ; \mathrm{OR}=6.8$; 95\% CI), Maternal Disease History ( $\mathrm{p}=0.006$; $\mathrm{OR}=8.41 ; 95 \% \mathrm{CI})$ and Perinatal History $(\mathrm{p}=0.021 ; \mathrm{OR}=4.3 ; 95 \% \mathrm{CI})$. It concluded that the most significant determinant on Perinatal Mortality was Maternal Disease History.
\end{abstract}

\section{Introduction}

Perinatal mortality rate (PMR) is one of public health indicator used as success parameter in health development program, beside maternal mortality rate (MMR) and infant mortality rate (IMR). Perinatal mortality rate (PMR) describe as number of deceased embrio delivered on 28 weeks maternity period or more and number of less than seven days ages infant mortality recorded for a year per 1000 birth on same year (Mahmudah, 2011).

Infant mortality rate in Nusa Tenggara Timur (NTT) on 2007 reached 57 per 1000 birth. On 2010 it decent to 39 . Then sadly head back to 45 on 2012 (Dinas Kesehatan Provinsi NTT, 2013). This is contraproductive to Mother and Child Health Revolution Program target for NTT which should be 32 on 2012 and 27 on 2013 (Provinsi NTT, 2009). Infant mortality in NTT from 2011 - 2013 showed fluctuative numbers. On 2011 was 1210 mortality. On 2012 was 1450 mortality. Later on 2013 was 1286 mortality. In terms of infant mortality indicate increasing trend. On 2011 was 1353, on 2012 was 1419 and on 2013 was 1461 (Dinas Kesehatan Provinsi NTT, 2013).

In spite of Kupang is NTT capitol, it contribute to high number of infant mortality in the province, specificly on perinatal period. On 2010 there was 126 cases of perinatal mortality, decreased to 56 cases on 2011 and then slight decrease to 55 cases on 2012 (Dinas Kesehatan

\footnotetext{
Correspondece Address:

Program Studi Ilmu Kesehatan Masyarakat

Pascasarjana Universitas Nusa Cendana Kupang, Indonesi

Email : dickaaprilio_sevenfoldism@yahoo.co.id
}

pISSN 1858-1196 
Kota Kupang, 2013). Infant mortality case at Kupang on 2013 was 6.35 per 1000 birth. This number is higher than Department of Health strategic plan which should be 4 per 1000 birth on 2013. It showed rising trend since on 2012 the number was 5 per 1000 and 2011 was 5,40 per 1000. On other occasion, on Division of Health Family recorded 52 infant mortality cases of 8187 born-alive and for post natal mortality case was recorded 29 cases (Dinas Kesehatan Kota Kupang, 2013).

Perinatal mortality is generally influenced by maternal factor which is grouped into maternal behavioural factor, maternal environtment factor, maternal heredity and maternal health services. Related with maternal health services, Health Profile NTT on 2013 reported that scope of maternity process served by health official on 2011 was $68,3 \%$, then on 2012 toll to $80,8 \%$ and decreased on 2013 became $77,7 \%$. As so $22,3 \%$ birth process remaining assisted by non health official. At Kupang there was $92,8 \%$ birth assisted by health practitioner and only $7,2 \%$ birth assisted by non health practitioner. Related with birth facility, Indonesia Health Profile on 2013 reported that in NTT there was $42,1 \%$ birth process taken place at home, $29,4 \%$ at Puskesmas/Pustu, $19,3 \%$ at hospital, $6,4 \%$ at Polindes/Poskesdes and 2,7\% at Maternity Center/Clinic/Health Practitioner (Rumah Bersalin/Klinik/Praktik Petugas Kesehatan). Related with maternal intrinsic risk factor, on 2013 in NTT, there were 24.987 (20,8\%) high risk pregnancies/complication and only 13.013 $(52,1 \%)$ were taken care of. At Kupang from 9.194 pregnancies, there were $1.973(21,5 \%)$ high risk pregnancies and only $1.213(61,5 \%)$ were taken care of. (Dinas Kesehatan NTT, 2013).

Research objective is to analyze (1) Relationbetween maternityhealthservices(Ante Natal Care (ANC), birth place, birth asistant, birth monitoring system and health financing) and perinatal mortality (2) Relation between maternal intrinsic risk factor (pregnancy age, maternal disease history,perinatal history and maternal nutritional status) and perinatal mortality (3) Relation between socio cultural factor (custom) and perinatal mortality (4) To build a model of perinatal mortality probability.

\section{Method}

Research method is analythic observational with case control design and conducted at 4 Public Health Care (Puskesmas) region on Kupang which are Puskesmas Sikumana, Puskesmas Alak, Puskesmas Pasir Panjang, and Puskesmas Oebobo representing 4 districts on Kupang, Maulafa, Alak, Kota Lama and Oebobo. Population is all mother experienced perinatal mortality on those districts in 2015, which reached 3346 mother. Number of cases recorded on the 4 Puskesmas are 49 (Dinas Kesehatan Kota Kupang, 2015). Sample size determined by case control sample on hypothesis test formula for odds ratio as follow :

$$
\begin{aligned}
\mathrm{n}= & \frac{\left\{\mathrm{Z}_{1-\alpha / 2} \sqrt{2 \mathrm{P}_{2}^{*}\left(1-\mathrm{P}_{2}^{*}\right)}+\mathrm{Z}_{1-\beta} \sqrt{\mathrm{P}_{1}^{*}\left(1-\mathrm{P}_{1}^{*}\right)+\mathrm{P}_{2}^{*}\left(1-\mathrm{P}_{2}^{*}\right)}\right\}^{2}}{\left(\mathrm{P}_{1}^{*}-\mathrm{P}_{2}^{*}\right)^{2}} \\
& =\frac{\{1.96 \sqrt{2 * 0.15(1-0.15)}+1.28 \sqrt{0.46(1-0.46)+0.15(1-0.15)}\}^{2}}{(0.46-0.15)^{2}} \\
& =\frac{3.25}{0.093}=34.95=35
\end{aligned}
$$

Sample in this research consist of case sample and control sample. Each consist of 35 individuals. Case and Control ratio is 1 : 1 so total sample is 70 individuals. Control sample is taken by simple random sampling technique. Primary data is taken by interview and measurement. Intruments used are questionnaire and LILA band (Upper arm circle).

Data collection are analyzed univariatly by bivariate frequence distribution using chisquare statistic $\left(\mathrm{X}^{2}\right)$ and multivariate using double logistic regression by statistic analysis program.

\section{Results and Discussion}

Kupang is capitol of Nusa Tenggara Timur (NTT) Province located on West Timor having $180,27 \mathrm{~km}^{2}$ which is $0,004 \%$ of NTT area $\left(47.349,9 \mathrm{~km}^{2}\right)$. Coordinate for this city lies between 10³6'14" $10^{\circ} 39^{\prime} 58^{\prime \prime}$ SL and between 12332'23" - 12337'01" WA (Dinas Kesehatan Kota Kupang, 2013)

It divided onto six administrative district Alak, Kota lama, Kota Raja, Kelapa Lima, Oebobo and Maulafa. Research is taken place on four Puskesmas region representing four district.

Analysis on Table 1 resulted that variable that contribute to risk of perinatal mortality on 
Table 1. Relation between ANC, Birth place, birth assistant, Birth Monitoring System, Health Financing, Maternal Age Maternal Disease History, Perinatal History, Maternal Nutritional Status, Custom and Tradition of Perinatal Mortality at Kupang.

\begin{tabular}{|c|c|c|c|c|c|c|c|c|c|}
\hline \multirow[t]{3}{*}{ ANC } & \multicolumn{4}{|c|}{ Perinatal Mortality } & \multirow{2}{*}{\multicolumn{2}{|c|}{ Total }} & \multirow[t]{3}{*}{$\mathrm{p}$} & \multirow[t]{3}{*}{ OR } & \multirow[t]{3}{*}{ CI 95\% } \\
\hline & \multicolumn{2}{|c|}{ Case } & \multicolumn{2}{|c|}{ Control } & & & & & \\
\hline & $\mathrm{N}$ & $(\%)$ & $\mathrm{n}$ & $(\%)$ & $\mathrm{n}$ & $\%$ & & & \\
\hline Incomplete & 11 & 15,7 & 8 & 11,4 & 19 & 27,1 & & & $0,53-4,48$ \\
\hline Complete & 24 & 34,3 & 27 & 38,6 & 51 & 72,9 & 0,420 & 1,55 & \\
\hline Total & 35 & 50,0 & 35 & 50,0 & 70 & 100,0 & & & \\
\hline \multirow[t]{3}{*}{ Birth Place } & \multicolumn{4}{|c|}{ Perinatal Mortality } & \multicolumn{2}{|c|}{ Total } & $\mathrm{p}$ & OR & CI 95\% \\
\hline & \multicolumn{2}{|c|}{ Case } & \multicolumn{2}{|c|}{ Control } & & & & & \\
\hline & $\mathrm{n}$ & $(\%)$ & $\mathrm{n}$ & (\%) & $\mathrm{n}$ & $\%$ & & & \\
\hline Non Health Facility/Insufficient & 8 & 11,4 & 7 & 10,0 & 15 & 21,4 & & & $0,38-3,72$ \\
\hline Sufficient Health Facility & 27 & 38,6 & 28 & 40,0 & 55 & 78,6 & 0,771 & 1,18 & \\
\hline Total & 35 & 50,0 & 35 & 50,0 & 70 & 100,0 & & & \\
\hline \multirow{4}{*}{ Birth Assistant } & \multirow{2}{*}{\multicolumn{4}{|c|}{ Perinatal Mortality }} & \multirow{2}{*}{\multicolumn{2}{|c|}{ Total }} & & & CI 95\% \\
\hline & & & & & & & $\mathrm{P}$ & OR & \\
\hline & \multicolumn{2}{|c|}{ Case } & \multicolumn{2}{|c|}{ Control } & & & & & \\
\hline & $\mathrm{n}$ & $(\%)$ & $\mathrm{n}$ & $(\%)$ & $\mathrm{n}$ & $\%$ & & & \\
\hline Non Medic/Family/Nurse & 3 & 4,3 & 0 & 0,0 & 3 & 4,3 & & & $1,63-2,7$ \\
\hline Midwife/ Obstetrician & 32 & 45,7 & 35 & 50,0 & 67 & 95,7 & 0,239 & 2,1 & \\
\hline Total & 35 & 50,0 & 35 & 50,0 & 70 & 100,0 & & & \\
\hline \multirow{3}{*}{ Birth Monitoring System } & \multicolumn{4}{|c|}{ Perinatal Mortality } & \multicolumn{2}{|c|}{ Total } & $\mathrm{P}$ & OR & CI 95\% \\
\hline & \multicolumn{2}{|c|}{ Case) } & \multicolumn{2}{|c|}{ Control } & & & & & \\
\hline & $\mathrm{n}$ & $(\%)$ & $\mathrm{n}$ & $(\%)$ & $\mathrm{n}$ & $\%$ & & & \\
\hline Risked & 30 & 42,9 & 25 & 35,7 & 55 & 78,6 & & & $0,72-7,95$ \\
\hline Unrisked & 5 & 7,1 & 10 & 14,3 & 15 & 21,4 & 0,145 & 2,4 & \\
\hline Total & 35 & 50,0 & 35 & 50,0 & 70 & 100,0 & & & \\
\hline \multirow[t]{3}{*}{ Health Financing } & \multicolumn{4}{|c|}{ Perinatal Mortality } & \multicolumn{2}{|c|}{ Total } & $\mathrm{P}$ & OR & CI 95\% \\
\hline & $\mathrm{Ca}$ & & & ntrol & & & & & \\
\hline & $\mathrm{n}$ & $(\%)$ & $\mathrm{n}$ & $(\%)$ & $\mathrm{n}$ & $\%$ & & & \\
\hline Without Health Financing & 14 & 20,0 & 3 & 4,3 & 17 & 24,3 & & & $1,82-27,8$ \\
\hline With Health Financing & 21 & 30,0 & 32 & 45,7 & 53 & 75,7 & 0,002 & 7,1 & \\
\hline Total & 35 & 50,0 & 35 & 50,0 & 70 & 100,0 & & & \\
\hline Maternal Age & & natal $N$ & Tortal & & Tota & & $\mathrm{P}$ & OR & CI 95\% \\
\hline & $\mathrm{Ca}$ & & & ntrol & lota & & & & \\
\hline & $\mathrm{n}$ & $(\%)$ & $\mathrm{n}$ & $(\%)$ & $\mathrm{n}$ & $\%$ & & & \\
\hline Risked & 8 & 11,4 & 5 & 7,1 & 13 & 18,6 & & & $0,52-6,1$ \\
\hline Unrisked & 27 & 38,6 & 30 & 42,9 & 57 & 81,4 & 0,356 & 1,78 & \\
\hline Total & 35 & 50,0 & 35 & 50,0 & 70 & 100,0 & & & \\
\hline
\end{tabular}




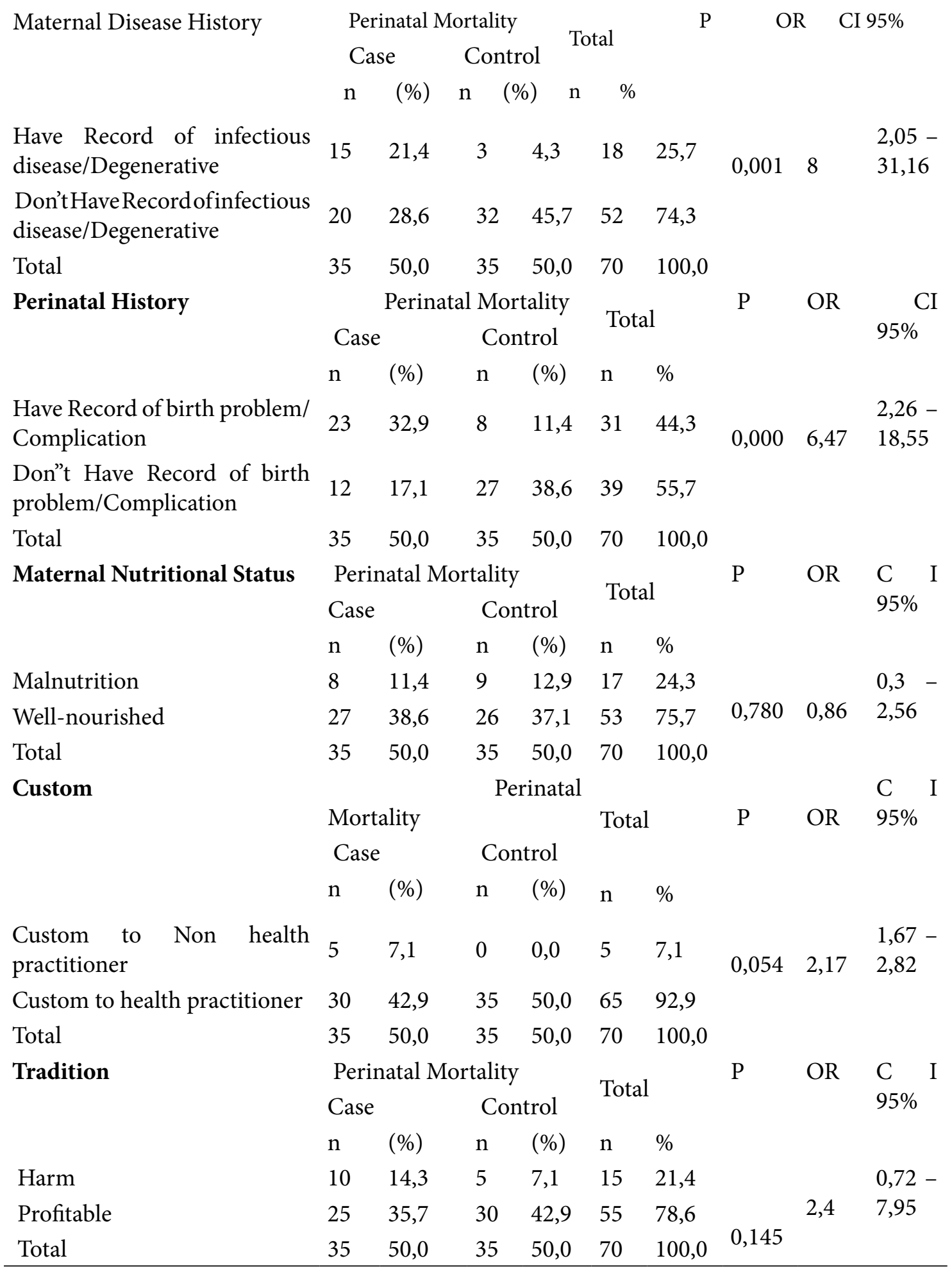

Source : Primary Data

Puskesmas region in Kupang is Birth Assistant $(\mathrm{OR}=2,1 ; 1,63-2,7 ; 95 \% \mathrm{CI})$, Health Financing (OR=7,1; 1,82-27,8; 95\%CI), Maternal Disease History $(\mathrm{OR}=8 ; 2,05-31,16)$, Perinatal History (OR=6,47; 2,26-18,55; 95\%CI) and custom/ culture $(\mathrm{OR}=2,17 ; 1,67-2,82 ; 95 \% \mathrm{CI})$. Variable of Birth Assistant ( $p=239)$ and custom/culture $(\mathrm{p}=054)$ still a potential submitting risk though relation test result by chi square not show significant relation $(\mathrm{p}>0,05)$. 
Tabel 2. Multivariance Analysis

\begin{tabular}{llllll}
\hline Variable & B & Sig. & OR & \multicolumn{2}{l}{$95.0 \%$ C.I. } \\
\cline { 5 - 6 } & & & & Lower & Upper \\
\hline Birth Assistant & 21,715 & 0,999 & $2,695 \mathrm{E} 9$ & 0,000 &. \\
Health Financing & 1,916 & 0,016 & 6,8 & 1,43 & 32,27 \\
Maternal Disease History & 2,129 & 0,006 & 8,41 & 1,84 & 38,36 \\
Perinatal History & 1,455 & 0,021 & 4,3 & 1,24 & 14,76 \\
Constant & $-1,678$ & 0,000 & 0,2 & & \\
\hline
\end{tabular}

Based on Table 1 also found that variables that can be followed with multivariance analysis with $\mathrm{p}<0,25$ which are birth assistant $(\mathrm{p}=0,239)$, birth monitoring system $(\mathrm{p}=0,145)$, health financing ( $\mathrm{p}=0,002)$, maternal disease history $(\mathrm{p}=0,001)$, perinatal history $(\mathrm{p}=0,000)$, custom/ culture $(\mathrm{p}=0,054)$ and tradition $(\mathrm{p}=0,239)$.

Result on table 2 multivariance analysis showed three variable consistently contribute prenatal mortality risk. They are health financing $(\mathrm{p}=0,016 ; \mathrm{OR}=6,8 ; 95 \% \mathrm{CI})$, maternal disease history $(\mathrm{p}=0,006 ; \mathrm{OR}=8,41 ; 95 \% \mathrm{CI})$, and perinatal history $(\mathrm{p}=0,021 ; \mathrm{OR}=4,3$; 95\%CI). From those three, maternal disease history is the dominant factor with highest OR. From Table 2, also can be conluded that probability model for perinatal mortality on Kupang formed by determinent variable which is health financing, maternal disease history and perinatal history.

Research result on Table 1 showed respondent obtained incomplete ANC (less than 4 times or more than 4 times yet not meet standard; K1 unavailable) are more appear on case group with 11 persons $(15,7 \%)$, while on control group 8 persons $(11,4 \%)$ appear. On Control group most of the respondent obtained sufficient ANC service (more than 4 times and meet the criteria) with 27 persons $(28,6 \%)$. Meantime, on Case group have 24 persons $(34,3 \%)$. Based on bivariant analysis result, it is found that ANC variable is not risk factor to perinatal mortality since OR is only 1,55 $(0,533-4,48)$ and not significant with perinatal mortality since $\mathrm{p}=0,420(\mathrm{p}>0,05)$.

This research is different compare to one on 2013, which ANC visit frequence variable significantly influence and one of risk factor in prenatal mortality with $\mathrm{OR}=10,403$. It is also different compare to Yani's research (2012) which stated that multivariance analysis showed antenatal care showed significant relation with neonatal mortality.

Researcher said, ANC that not being to risk factor of perinatal mortality is due to the mother has obtained sufficient and well treated ANC whether in case group or in control group. The proportion was 72,9 with sufficient ANC and $27,1 \%$ with insufficient one.

From table 1 it can be seen that respondent giving birth at non health facility (home) or insufficient health facility (Puskesmas Pembantu/Puskesmas non-PONED) in case group is 8 persons (11.4\%), slightly larger than control group which is 7 persons (10\%). On control group, most of the respondent giving birth at sufficient health facility (Puskesmas PONED/Hospital) with 28 persons (40\%), as so with case group respondent with 27 persons (38.6\%). By bivariance analysis can be obtained that birth place is not risk factor of perinatal mortality since the OR is only $1.18(0.38-3.72)$ dan unsignificantly related with perinatal mortality since the $\mathrm{p}=0.771$ ( $\mathrm{p}>0.05)$.

Research result is different with one conducted by Tachiweyika (2011) on Marondera District, Zimbabwe stating home birth (not on health facility) increase risk to perinatal mortality with OR 7.38. Different result also showed by Wax research (2010) in US concluding home birth (non health facility) had relation wih high neonatal mortality. Yet this research result is aligned with Birthplace in England Collaborative Group (2011) in England showing no different between planned home birth and hospital birth.

Researcher said, birth place variable is not risk factor of perinatal mortality since mother proportion giving birth at sufficient health facility, whether at Puskesmas PONED 
or hospital is large enough on both case group and control group. The proportion is $78.6 \%$ (55 mother) giving birth at suffcient health facility and $21.5 \%$ (15 mother) at insufficient health facility. This has meet NTT Mother and Child Health Revolution Policy (2009) which stated that to reduce level of mother and infant mortality then birth process should be done at sufficient health facility as Puskesmas PONED or Rumah Sakit PONEK.

Research result on Table 1 indicated respondent get birth assistant by family or non medical person like traditional birth assistant only occur on case group with 3 persons $(4.3 \%)$ when none on control group. Based on bivariance analysis, can be known that birth assistant is risk factor of perinatal mortality with OR 2.1 (1.63-2.7). It represent that a mother helped by non health assistant during birth process (family or traditional birth assistant) risk 2.1 times higher to have perinatal mortality compare to mother that being helped by health practitioner (midwife/obstretician). Yet this variable has no significant relation with perinatal mortality due to $\mathrm{p}=0.239$ ( $\mathrm{p}>0.05)$. On multivariance analysis (table 2 ) this variable no longer concerned as risk factor due to $\mathrm{OR}=0$ and $\mathrm{p}=0.999$.

This is aligned with research by Yani (2012) and Mahmudah (2011), stated no significant relation between birth assistant with perinatal and neonatal mortality with each $\mathrm{p}=0.31$ and 0.0 .065 . Same statement from Jokhio (2005), in Pakistan which shown traditional birth assistant with sufficient training in fact effectively and bravely decrease perinatal mortality in developed country. Aligned with Carlo (2010), in 6 developed country (Argentina, Congo, Guatemala, India, Pakistan and Zambia) giving picture of neonatal resusitation training effect to birth assistant apparently not decrease early neonatal mortality.

According to researcher, birth assistant has no longer been a risk factor of perinatal mortality by multivariance analysis since nearly all respondent (mother) whether in case or control group has been helped in birth process by health practitioner with 67 persons (95.7\%) and only 3 persons (4.3\%) is helped by family or non health assistant.
Research result on Table 1 showed that respondent numbers who do not have birth monitoring system or not came into proper health facility few days before estimated birth day (birth day $=$ health facility check in day) is higher on case control with 30 persons (42.9\%) while control group has a slight difference with 25 persons (35\%). Number of respondents who have birth monitoring system or have been on sufficient health facility few days earlier than estimated birth day ( $\mathrm{H}-1$ and $\mathrm{H}+3$ for normal pregnancy and $\mathrm{H}-7$ and $\mathrm{H}+7$ for high risk pregnancy) are quite low, both on case group and control group. Yet, the number is higher on control group. With 10 persons (14.3\%) on control group and 5 persons (7.1\%). Based on bivariate analysis result, birth monitoring system variable does not contribute to perinatal mortality risk since the OR is $2.4(0.72-7.95)$ and does not have significant relation with perinatal mortality since the $\mathrm{p}$ is 0.145 ( $\mathrm{p}>0.05)$. Consistantly, based on multivariate analysis, this variable does not a perinatal mortality risk factor with $\mathrm{p}>0.05$.

This does not aligned with Dewi (2011), stated that problem in pregnancy and perinatal caused by malfunction birth monitoring system by health practitioner due to lateness to sufficient health facility for reasons of distance, transportation, road condition and cost. As well as lateness in proper treatment. If birth monitoring system is well being then it can be predicted time of perinatal so whether normal or high risk condition mother can be prepared or well planned.

Researcher said, birth monitoring system that not contribute to perinatal mortality risk factor is caused by large respondent proportion, both on case group and control group related with malfunction birth monitoring system. From all respondent, 55 persons (78.6\%) were going through malfunction (risked) birth monitoring system. While respondent with functioned (unrisked) birth monitoring system are 15 persons (21.4\%) only. It can be condluded that they were more likely to come to health facility when they were going to deliver the baby or when contraction was felt dan directly left the day after the baby had been delivered. Only few respondent had been on sufficient health facility few days before estimated birth 
day ( $\mathrm{H}-1$ for normal condition and $\mathrm{H}-7$ for high risk condition) and left the facility few days after the birth day $(\mathrm{H}+1$ for normal condition and $\mathrm{H}+7$ for High risk condition) as adviced by NTT Revolutionary Mother and Child Health Policy (2009). It can be said that Health service related with birth monitoring system has not well function, probably trigerred by uncorrect birth date by health service attendant.

Result on table 1 showed that number of respondent who does not get government fund either direct fund or cost free or uninsuranced is larger on case group with 14 persons (20\%), while on control group is 3 persons only (4.3\%). On control group, most of the respondent obtained government fund either direct fund or cost free or insuranced with 32 persons (45.7\%) while on case group is less with 21 persons (30\%). Based on bivariate analysis, can be known that health financing variable is one of perinatal mortality risk factor with OR $7.1(1.82-27,8)$ which mean mother without government fund either direct fund or cost free or uninsuranced to finance her maternity period (pregnancy, birth and after birth) has possibility to experience prenatal mortality 7.1 times higher compare to mother with government fund either direct fund or cost free or insuranced. This variable is significantly related with prenatal since $\mathrm{p}$ value $=0.002$ $(\mathrm{p}<0.05)$. On multivariate analysis (table 2$)$, it still consistantly become risk factor related with perinatal mortality with $\mathrm{OR}$ value $=6.8$ and $\mathrm{p}=0.016(\mathrm{p}<0.05)$.

This result aligned with one conducted by Zahtamal (2011), in Riau, stated that payment method related with health financing is free variable that has firm connection with infant health with $\mathrm{p}$ value $=0.001$ and $P R=4.884$. The result also support Fuadi in Zahtamal (2011), mentioning self health payment is economically suffering to mother and the family since health cost do expensive so they can't access sufficient health service.

Based on this research, obtained that 17 respondents $(24.3 \%)$ of 70 respondents who used personal finance for birth cost, where 14 respondents are member of case group (experienced perinatal mortality). It can be concluded that if a mother does not obtained any assistance to finance her maternal health (during pregnancy, birth and after birth), whether from government or health insurance, then she will have to self financing. Since personal economic capability is various, if the mother and family is economically weak, she will choose less cost health service though it does not sufficient event she could decide not to access at all. This will increase the risk of perinatal mortality, specifically on mother with complication or high risk health condition.

Research result on table 1 showed number or respondents with risk maternal age $(<20$ years and $>35$ years $)$ are more on case group with 8 persons $(11.4 \%)$ while on control group has 5 persons (7.1\%). On control group most of respondent is 20-35 years old (unrisk maternal age) which 30 persons (42.9\%). As so with case group with 27 persons (38.6\%). Based on bivariate analysis, can be known that maternal age variable does not a perinatal mortality risk factor since OR value only 1.78 (0.52-6.1) and does not significantly related with perinatal mortality since $\mathrm{p}$ value $=0.356$ $(\mathrm{p}>0.05)$.

This aligned with previous research on 2013 on Kupang where maternal age variable does not have significant relation with perinatal mortality with $\mathrm{p}=1.000(\mathrm{p}>0.05)$. As well as Mahmudah (2011) claimed that no significant relation between maternal age and perinatal mortality with $\mathrm{p}=0.503(\mathrm{p}>0.05)$. Yet this result does not aligned with Yani (2012) figured age is disturbing variable significantly related with neonatal mortality with $\mathrm{p}=0.00$ and OR 16.32 . The result also contradicted with Prabamurti (2006) stated that there is relation between maternal age and neonatal mortality.

This research enforce previous research showing maternal age variable consistantly does not a risk factor of prenatal mortality on Kupang because proportion of maternal age 20-35 years old (unrisk age) is larger than risk age ( $<20$ years old and $>35$ years old) both on case group and control group. Total proportion between maternal with unrisk age and risk age is $81.4 \%$ and $16.6 \%$.

Result on Table 1 showed respondent with infectious diseases history or degenerative are larger on case group with 15 persons (21.4\%). While on control group only 3 persons (4.3\%). On Control group, most of the 
respondent does not have infectious diseases history or degenerative with 32 persons (45.7\%) while on case group 20 persons (28.6\%). Based on bivariate analysis, obtained that maternal disease history variable is perinatal mortality risk factor with OR value $8(2.05-31.16)$ so possibility for mother with infectious diseases record or degenerative or diesease related with pregnancy and birth is 8 times larger than they who don't have such record. This variable has significant relation with perinatal mortality with $\mathrm{p}$ value $0.001(\mathrm{p}<0.05)$. Based on multivariate analysis, (table 2) showed same result with OR $=8.41$ and $\mathrm{p}=0.006(\mathrm{p}<0.05)$.

This result aligned with Yani (2012), found out that bivariately there is significant relation between maternal disease history with neonatal mortality $(\mathrm{p}=0.01$ and $\mathrm{OR}=4.76)$. As well as Ananth and Wilcox research (2001) in US said disease experienced by mother in mid pregnancy period such as placental failure related with infant weight and prenatal perinatal mortality. Also same with Bayou (2012) in Ethiopia said that hypertension during pregnancy and ante partum bleeding has relation with infant mortality and early neonatal mortality.

Result of this research support Dewi (2011) claimed past and current maternal disease history can help health practitioner to identify health condition of pregnancy and new born as so help to reduce complication and mother and infant mortality risk. Maternal disease history in this context is related with direct complication such as preecclamps and ecclamps, antepartum bleeding and early fetal membrane breaks. As well as complicated disease such as diabeteus mellitus, anemia, hypertension, coroner heart, asthma and sexual infectious disease.

On Table 1 shown that number or respondent with previous problem perinatal history /complication or does not have first birth experience is larger on case group with 23 persons $(32.9 \%)$ while on control group only 8 persons (11.4\%). On control group nearly most of respondent does not have normal previous birth experience with 27 persons (38.6\%) while on case group only 12 persons (17.1\%). Based on bivariate analysis result, obtained that perinatal history variable is perinatal mortality risk factor with OR 6.47 (2.26-18.55). It mean possibility of mother with problem perinatal history /complication or does not have first birth experience is 6.47 larger than they who have normal previous birth record. This variable also have significant relation with perinatal mortality with $\mathrm{p}=0.000(\mathrm{p}<0.05)$. In multivariate analysis (table 2 ), this variable consistently become risk factor related with perinatal mortality with OR 4.3 and $\mathrm{p}=0.021$ $(\mathrm{p}<0.05)$.

This result aligned with Yani's (2012) found bivariately there is significant relation between perinatal history and neonatal mortality ( $\mathrm{p}=0.03$ and $\mathrm{OR}=7.39)$. Also support Dewi (2011), stated that past difficulty on pregnancy or perinatal and frequent pregnancy fails frequency of miscarriage is one of high risk maternity condition. Perinatal history consist of number of pregnancy, born-alive, aterm birth, preterm birth, miscarriage, assisted birth with forcep or sexio cesarea, bleeding during pregnancy, birth experience, infant weight less than 2500 gr or more than 4000 gr and other problems.

Result on table 1 showed respondent with malnutrition (LILA $<23.5 \mathrm{~cm}$ ) is larger on control goup with 9 persons (12.9\%) while on case group 8 persons (11.4\%). On case group nearly most of the respondent has wellnourished $(\geq 23 \mathrm{~cm})$ with 27 persons $(38.6 \%)$ as well as on control group with 26 persons (37.1\%). Based on bivariate analysis maternal nutritional status is not perinatal mortality risk factor since OR is $0.86(0.3-2.56)$ and does not have significant relation with perinatal mortality since $\mathrm{p}=0.78(\mathrm{p}>0.05)$.

Research by Prabamurti (2006), showed different result. It said there is relation between low birth weight infant with neonatal mortality $(\mathrm{p}=0.016$ and $\mathrm{OR}=6.12)$. Jaya (2009), showed that maternal nutritional status is risk factor for low birth weight infant (Berat Badan Bayi Lahir Rendah =BBLR) with OR value 9.94. while Djaja (2002) said highest reason for early neonatal mortality (0-7 days) is low birth weight infant $35 \%$.

Researcher said, maternal nutritional status is not risk factor of perinatal mortality due to well-nourished mothers proportion (LILA $\geq 23,5 \mathrm{~cm}$ ) is higher than malnutrition 
mothers (LILA $<23,5 \mathrm{~cm}$ ) both on case group and control group. Total proportion is $75.5 \%$ and $24.3 \%$.

Result on table 1 showed number of respondent commonly choose non health practitioner (family or traditional birth assistant) to help birth process only lies on case group with 5 persons $(7.1 \%)$ while all control group (100\%) has commonly choose competent health official to help birth process. Nearly most of case group respondent has commonly choose competent health official to help birth process with 30 persons $(42.9 \%)$. Based on bivariate analysis can be obtained that custom variable (culture) is perinatal risk factor with OR value 2.17 (1.67-2.82) which indicate mother who commonly choose non health practititioner (family or traditional birth assistant) to help birth process has 2.17 risk larger to experience perinatal mortality. Yet this variable is not have significant relation with perinatal mortality since the $\mathrm{p}=0.054(\mathrm{p}<0.05)$. On multivariate analysis, this variable no longer consider related with perinatal mortality since $\mathrm{p}>0.05$.

This result different than Juliwanto in Zahtamal (2011), stated that there are still many believes in community that not suitable with health values become deciding factor in poor public health service, such as common habit in choose birth assistant. Parenden (2014) also showed that mother habit to choose birth process assistant strongly related with local tradition/culture. Amalia (2012), showed same result, there is socio cultural influence in birth process assistant choosing with $\mathrm{p}$ value $=$ 0.010 . Poor public health service certainly has potential to produce insufficient output such as infant mortality.

Researcher said custom/habit variable is no longer risk factor of perinatal mortality based on multivariate analysis due to most of all respondent (maternal) both case and control group have commonly choose health practitioner (midwife/obstretician) to help birth process with 65 persons $(92.9 \%)$ and only 5 persons $(7.1 \%)$ still choose non health practitioner like family or traditional birth assistant in birth process.

Result on table 1 showed respondent with $\mathrm{Se} \mathbf{i} /$ Tatobi/food taboos is larger on case group with 10 persons (14.3\%), while on control group is 5 persons (7.1\%). On control group most of respondent does not have such habit with 30 persons (42.9\%). Same with case group respondent with 25 persons (35.7\%). Based on bivariate analysis, obtained that tradition variable is not perinatal mortality risk factor since OR value 2.4 (0.72-7.95) and does not have significant relation with perinatal mortality since the $\mathrm{p}$ value is 0.145 ( $\mathrm{p}>0.05)$. On multivariate analysis, this variable has same condition with $\mathrm{p}>0.05$.

This result not aligned with Zahtamal (2011), on Riau stated there are still many believes or tradition in the community that do not aligned with health value specifically to mother and child health. Descriptively, Zahtamal said that 274 persons respon to question of applied traditions or believes in daily live related with maternity health, obtained that 124 persons (45.26\%) have believes that do not aligned with health values. The traditions or believes mostly related with pregnancy and infant health. Pasaribuan (2014), also stated descriptively from culture aspect, mostly maternity on Kabupaten Deli Serdang has believe or tradition that does not support health pregnancy, such as refuse to eat fish (38.88\%), sticky rice $(24.07 \%)$, pineapple $(20.37 \%)$ and banana. Different with this research with respondent proportion has negative tradition like Se'i and Tatobi only $21.4 \%$ (15\%) while 55 respondent (78.6\%) don't have negative culture anymore.

Researcher said, a quite numerous of mother proportion who do not refuse to certain food. Like Se'i or Tatobi is the reason of tradition varible is not risk factor of perinatal mortality.

\section{Conclusions}

Risk factors of health service consistently influence perinatal mortality is health financing $(\mathrm{p}=0.016 ; \mathrm{OR}=6.8)$. Maternal intrinsic risk factor consistently influence perinatal mortality are maternal disease history $(\mathrm{p}=0.006 ; \mathrm{OR}=8.41)$ and perinatal history $(\mathrm{p}=0.021 ; \mathrm{OR}=4.3)$. All Variables in socio cultural factor inconsistently influence perinatal mortality. Advice to Kupang City Government is to increase maternity health budget to decrease perinatal mortality rate at Kupang.

\section{References}

Amalia, Lia. 2012. Faktor - Faktor yang 
Mempengaruhi Ibu dalam Pemilihan Penolong Persalinan. Artikel Penelitian. Jurnal Sainstek Universitas Negeri Gorontalo, 7 (2)

Ananth, Cande. 2001. Placental Abruption and Perinatal Mortality in the United States. Artikel Jurnal Penelitian. American Journal of Epidemiology, 153 (4)

Bayou, Getachew. 2012. Perinatal Mortality and Associated Risk Factors : A Case Control Study. Jurnal Penelitian. Ethiop J Health Science, 22 (3) : 153-162.

Birthplace in England Collaborative Group. 2011. Perinatal And Maternal Outcomes By Planned Place Of Birth For Healthy Women With Low Risk Pregnancies. The Birthplace in England national prospective cohort study. Artikel Jurnal Penelitian. BMJ

Carlo, Waldemer, et al. 2010. New - Born Care Training and Perinatal Mortality in Developing Countries. Artikel Jurnal Penelitian. The New England Journal of Medicine, $362: 614-23$

Dewi, Vivian dan Sunarsih, Tri. 2011. Asuhan Kehamilan untuk Kebidanan. Jakarta: Salemba Medika

Dinas Kesehatan Kota Kupang. 2013. Profil Kesehatan Kota Kupang. Kupang: Dinkes Kota Kupang

Dinas Kesehatan Provinsi NTT. 2013. Profil Kesehatan Provinsi NTT. Kupang: Tim Analisis Data Dinas Kesehatan Provinsi NTT

Djaja, Sarimawar. 2002. Penyebab Kematian Bayi Baru Lahir (Neonatal) dan Sistem Pelayanan Kesehatan yang Berkaitan di Indonesia Survei Kesehatan Rumah Tangga (SKRT) 2001. Buletin Penelitian Kesehatan, 31 (3)

Jaya, Ningsih. 2009. Analisis Faktor Resiko Kejadian Bayi Berat Lahir Rendah di Rumah Sakit Ibu dan Anak Siti Fatimah Kota Makassar. Artikel Jurnal Penelitian. Media Gizi Pangan, 7 (1)
Jokhio, Abdul Hakeem, et al. 2005. An Intervention Involving Traditional Birth Attendants and Perinatal and Maternal Mortality in Pakistan. Artikel Jurnal Penelitian. The New England Journal of Medicine, 352 : 2005-2091

Mahmudah, Ummul. 2011. Faktor Ibu dan Bayi yang Berhubungan dengan Kejadian Kematian Perinatal. Artikel Jurnal Penelitian. Jurnal Kesehatan Masyarakat, 7 (1) : 41 - 50

Parenden, Relik. 2014. Analisis Keputusan Ibu Memilih Penolong Persalinan di Wilayah Puskesmas Kabila Bone. Artikel Penelitian. JIKMU, 5 (2a)

Pasaribuan, Rina. 2014. Sosial, Budaya serta Pengetahuan Ibu Hamil yang Tidak Mendukung Kehamilan Sehat. Artikel Penelitian. Pannmed, 9 (1)

Prabamurti, Priyadi Nugraha. 2006. Analisis Faktor Risiko Status Kematian Neonatal. Artikel Penelitian. Jurnal Promosi Kesehatan Indonesia, 3 (1)

Provinsi NTT. 2009. Pedoman Revolusi KIA di Provinsi NTT(Pergub, Juklak dan Juknis). Kupang: Dinas Kesehatan

Tachiweyika Emmanuel, et al. 2009. Determinants of perinatal mortality in Marondera district, Mashonaland East Province of Zimbabwe, 2009: a case control study. Artikel Jurnal Penelitian. The Pan African Medical Journal

Wax, Joseph, et al. 2010. Maternal and newborn outcomes in planned home birth vs planned hospital births : a metaanalysis. Artikel Jurnal Penelitian. American Journal of Obstetrics \& Gynecology 2010 : 203-243

Yani, Desy Fitri. 2012. Pelayanan Kesehatan Ibu dan Kematian Neonatal. Artikel Penelitian. Jurnal Kesmas Nasional, 7 (8)

Zahtamal. 2011. Analisis Faktor Determinan Permasalahan Pelayanan Kesehatan Ibu dan Anak. Artikel Penelitian. Jurnal Kesmas Nasional, 6 (1) 